\title{
On the uniform convergence of a $q$-series
}

\section{OCTAVIAN AgRATINI and ViJAY GUPTA}

\section{ABSTRACT.}

The paper deals with a class of linear positive operators expressed by $q$-series. By using modulus of smoothness an upper bound of approximation error is determined. We identify functions for which these operators provide uniform approximation over noncompact intervals. A particular case is delivered.

\section{REFERENCES}

[1] Acar, T. and Ulusoy, G., Approximation by modified Szász-Durrmeyer operators, Period. Math. Hungar., 72 (2016), No. 1, 64-75

[2] Agratini, O. and Radu, C., On q-Baskakov-Mastroianni operators, Rocky Mountain J. Math., 42 (2012), No. 3, 773-790

[3] Andrews, G. E., $q$-Series: Their Development and Applications in Analysis, Number Theory, Combinatorics, Physics and Computer Algebra, Conference Board of the Mathematical Sciences, Number 66, American Mathematical Society, 1986

[4] Aral, A., A generalization of Szász-Mirakjan operators based on q-integers, Math. Comput. Modelling, 47 (2008), 1052-1062

[5] Aral, A. and Doğru, O., Bleimann, Butzer and Hahn operators on the q-integers, J. Ineq. Appl., Art. ID79410 (2007), 1-12

[6] Aral, A., Gupta, V., On certain q Baskakov-Durrmeyer operators, Creat. Math. Inform, 22 (2013), No. 1, 1-8

[7] Aral, A., Gupta, V. and Agarwal, R. P., Applications of $q$-Calculus in Operator Theory, Springer Science \& Business Media New York, 2013

[8] Baskakov, V. A., An example of a sequence of linear positive operators in the space of continuous functions, Dokl. Akad. Nauk. SSSR, 113 (1957), 249-251

[9] Bărbosu, D., Acu, A.- M. and Sofonea, F. D., The Voronovskaja-type formula for the Bleimann, Butzer and Hahn operators, Creat. Math. Inform., 23 (2014), No. 2, 137-140

[10] Bărbosu, D., Pop, O. T. and Miclăuş, D., On some extensions for the Szász-Mirakjan operators, An. Univ. Oradea Fasc. Mat., 18 (2011), No. 1, 179-187

[11] Bărbosu, D., Pop, O. T. and Miclăuş, D., The Kantorovich form of some extensions for Szász-Mirakjan operators Rev. Anal. Numér. Théor. Approx., 39 (2010), No. 1, 8-20

[12] Bărbosu, D., Generalized blending operators of Favard-Szász type, Bul. Ştiinţ. Univ. Baia Mare Ser. B, 10 (1994), No. $1-2,45-51$

[13] Doğru, O. and Duman, O., Statistical approximation of Meyer-König and Zeller operators based on the q-integers, Publ. Math. Debrecen, 68 (2006), 199-214

[14] Gupta, V. and Sharma, H., Statistical approximation by q-integrated Meyer-König-Zeller-Kantorovich operators, Creat. Math. Inform., 19 (2010), No. 1, 45-52

[15] Lorentz, G. G., Bernstein Polynomials, 2nd Ed., Chelsea Publ. Comp., New York, NY, 1986

[16] Lupaş, A., A q-analogue of the Bernstein operators, Seminar on Numerical and Statistical Calculus (ClujNapoca, 1987), 85-92, Preprint, 87-9, Univ. "Babes-Bolyai", Cluj-Napoca, 1987

[17] Kac, V. and Cheung, P., Quantum Calculus, Universitext, Springer-Verlag, New York, 2002

[18] Mahmudov, N. I., Approximation by the q-Szász-Mirakjan operators, Abstr. Appl. Anal., 2012, Art. ID 754217, $16 \mathrm{pp}$.

[19] Mastroianni, G., Su un operatore lineare e positivo, Rend. Acc. Sc. Fis. Mat., Napoli, Serie IV, 46 (1979), 161-176

Received: 10.04.2015; In revised form: 18.11.2015; Accepted: 25.11.2015

2010 Mathematics Subject Classification. 05A30, 26 D15.

Key words and phrases. $q$-series, approximation process, modulus of smoothness, rate of convergence.

Corresponding author: Octavian Agratini; agratini@math.ubbcluj.ro 
[20] Mishra, V. N. and Sharma, P., On approximation properties of Baskakov Schurer Szász operators, Appl. Math. Comput., 281 (2016), 381-393

[21] Mursaleen, M., Alotaibi, A. and Ansari, K. J., On a Kantorovich Variant of $(p, q)$-Szász-Mirakjan operators, J. Funct. Spaces 2016, Art. ID 1035253, 9 pp.

[22] Ostrovska, S., On the Lupaş q-analogue of the Bernstein operator, Rocky Mountain J. Math., 36 (2006), No. 5, $1615-1629$

[23] Pop, O. T., Miclăuş, D. and Bărbosu, D., The Voronovskaja type theorem for a general class of Szász-Mirakjan operators, Miskolc Math. Notes, 14 (2013), No. 1, 219-231

[24] Pop, O. T., Bărbosu, D. and Micăuş, D., The Voronovskaja type theorem for an extension of Szász-Mirakjan operators, Demonstratio Math., 45 (2012), No. 1, 107-115

[25] Trif, T., Meyer-König and Zeller operators based on the q-integers, Rev. Anal. Numér. Théor. Approx., 29 (2000), 221-229

[26] Sharma, H. and Gupta, C., On $(p, q)$-generalization of Szász-Mirakyan Kantorovich operators, Boll. Unione Mat. Ital., 8 (2015), No. 3, 213-222

BABEŞ-BOLYAI UNIVERSITY

FACULTY OF MATHEMATICS AND COMPUTER SCIENCE

KOGĂLNICEANU 1, 400084 CLUJ-NAPOCA, ROMANIA

E-mail address: agratini@math.ubbcluj.ro

SCHOOL OF APPLIED SCIENCES

Netaji SubHas Institute of TeChNOLOgy

NEW DELHI, INDIA

E-mail address: vijaygupta2001@hotmail.com 